\title{
Chemical speciation of fine particle bound trace metals
}

\author{
${ }^{1,2}$ X. D. Feng; ${ }^{1 *}$ Z. Dang; ${ }^{2}$ W. L. Huang; ${ }^{1}$ C. Yang \\ ${ }^{1}$ School of Environmental Science and Engineering, South China University of Technology, Guangzhou Higher \\ Education Mega Center, Guangzhou, 510006, P.R. China \\ ${ }^{2}$ Department of Environmental Sciences, Rutgers University, New Brunswick, New Jersey, 08901-8551, USA
}

Received 28 August 2008; $\quad$ revised 21 January 2009; accepted 2 May 2009; available online 1 June 2009

\begin{abstract}
This study reported quantifications of fine particle bound trace metals and their potential health risks for residents in Guangzhou, a rapidly developing and most populated city in South China. The fine particle samples were collected from October $29^{\text {th. }}$ to November $8^{\text {th. }}$ of 2006 at two different elevations in a mainly residential area and analyzed for the total concentration of aluminum, iron, zinc, lead, manganese, copper, arsenic, chromium, nickel, cadmium, molybdenum and cobalt. Results showed that the fine particle concentrations ranged from 95.8 $\mu \mathrm{g} / \mathrm{m}^{3}$ to $194.7 \mu \mathrm{g} / \mathrm{m}^{3}$ at the ground and $83.3-190.0 \mu \mathrm{g} / \mathrm{m}^{3}$ on the roof, which were much higher than the $24 \mathrm{~h}$ fine particle standard $\left(35 \mu \mathrm{g} / \mathrm{m}^{3}\right)$ recommended by USEPA. The total concentrations of zinc, lead, arsenic, chromium and cadmium in fine particle were 504.8, 201.6, 24.3, 7.7 and $4.4 \mathrm{ng} / \mathrm{m}^{3}$, respectively, which were comparable to other major cities of China, but much higher than major cities outside of China. A sequential extraction procedure was used to fractionate these fine particle bound metals into four different fractions. Results indicated that most toxic metals were mainly distributed in bioavailable fractions. For instance, about $91 \%$ of cadmium, $85 \%$ of lead and $74 \%$ of arsenic were in bioavailable forms. Risk calculations with a simple exposure assessment model showed that the cancer risks of the bioavailable fractions of arsenic, chromium and cadmium were 3 to 33 times greater than usual goal, indicating serious health risks to the residents in this urban area.
\end{abstract}

Keywords: Bioavailability; Fine particle; Health risk assessment; Sequential extraction procedure; Trace element

\section{INTRODUCTION}

Trace metals associated with air-borne particulate matter (PM) have different speciations or fractions that exhibit different bioavailability and potential risk to human beings. A labile fraction of the particle-bound metals is considered to be more readily available to environmental receptors and hence possesses greater environmental risk than the resistant fraction. Previous studies reported that trace metal contents of airborne $\mathrm{PM}$ and in particular the water-soluble fraction, are correlated positively with the observed pulmonary toxicity (Adamson et al., 2000; Sun et al., 2001). Adamson et al. (2000) found that $1 \mathrm{mg}$ of respirable range atmospheric particulate material (EHC-93), which had $99 \%$ of particles $<3.0 \mu \mathrm{m}$ and $45 \%$ of $\mathrm{Zn}$ in soluble fraction, can induce inflammatory cells and protein in lung lavage fluid and DNA synthesis in lung cells. Fine particle $\left(\mathrm{PM}_{2.5}\right)$, with aerodynamic diameter smaller than $2.5 \mu \mathrm{m}$, is considered to be more hazardous than larger

$\triangle$ *Corresponding Author Email: chzdang@scut.edu.cn Tel.: +8620 3938 0522; Fax: +8620 39380569 size PM due to its longer residence time in the atmosphere and can penetrate deep into the alveolus of human beings through breathing (Ormstad, 2000; Peters et al., 2001). Previous study (Heal et al., 2005) showed that water soluble form, the most readily bioavailable form, is the dominant fraction of $\mathrm{PM}_{2.5}{ }^{-}$ bound heavy metals in urban atmospheres of developed countries where automobile emission is a major source of $\mathrm{PM}_{2.5}$.

Quantification of labile versus resistant fractions of particle-bound metals has not been standardized in the literature. Sequential chemical fractionation is an important method for determining the actual metal activity in the environment (Fernández et al., 2000). The sequential extraction procedure (SEP) reported by Tessier et al. (1979) and the BCR three-step sequential extraction procedure drew up by the European Community's Bureau of References (Ure et al., 1993) are the most representative procedures and have been widely applied for operationally defined phases or 
fractions of metals associated with environmental solids including soils, sediments, suspended particulate materials, as well as urban street dusts (Banerjee, 2003; Davidson et al., 1998; Usero et al., 1998). Fernández et al. (2002) developed a four-step SEP for fractionating PM-bound metals and for quantifying labile metal fractions that are potentially available to the respiratory tract of the human body. The procedure was used in several exposure studies for measuring the bioavailable fractions of toxic metals associated with PM (Gómez et al., 2007; Sammut et al., 2006).

This study focused on the chemical speciation of trace metals associated with $\mathrm{PM}_{2.5}$ in Guangzhou, a rapidly developing and most populated city in South China. Previous studies on $\mathrm{PM}_{2.5}$-bound trace metals of Guangzhou city have centered on total concentration measurements (Lee et al., 2007; Wang et al., 2006), little is known on the chemical speciation of these $\mathrm{PM}_{2.5}$-bound metals (Karbassi and Shankar, 1994). Due to high air pollution and multiple sources of PM, compositions of $\mathrm{PM}_{2.5}$ and chemical speciation of $\mathrm{PM}_{2.5}$-bound trace metals in this area may be different from those of the well developed urban areas. Therefore, studies on chemical speciation are thus much needed for evaluating the bioavailability and health risk of $\mathrm{PM}_{2.5}$-bound trace metals in this area, and important for establishing emission standards among different industries and other emission sources.

The overall goal was to assess the bioavailability and the potential health risk of $\mathrm{PM}_{2.5}$-bound trace metals for residents in Guangzhou city by quantifying the total concentration and characterizing the chemical speciation. The incremental lifetime cancer risks were evaluated using the literature toxicity data and the speciation data of selected trace metals. The study provided important information on the baseline data of toxic metals and their potential health risks to the residents due to inhalation of $\mathrm{PM}_{2.5}$ in Guangzhou urban area. This study has been done in Guangzhou, China during October, 2006 to March, 2007.

\section{MATERIALS AND METHODS}

\section{$P M_{2.5}$ Sampling}

A sampling site located within the campus of South China University of Technology (SCUT), northeast of Guangzhou was selected (Fig. 1). The $\mathrm{PM}_{2.5}$ samples were collected from two different elevations, one at the ground level and the other on the roof of a four-story $15 \mathrm{~m}$ high building. The sampling site was surrounded directly by four chemistry research laboratories and two small construction sites. Several university office buildings, residential apartment buildings, including dormitories were 200 to $400 \mathrm{~m}$ away. Three major highways were also $200 \mathrm{~m}$ to $2 \mathrm{~km}$ away from the site. It is expected that the sources of PM were mixed and were typical of PM in this urban area of Guangzhou.

A total of twenty $\mathrm{PM}_{2.5}$ samples were collected on quartz microfiber membrane filters (QMWhatman, $20.3 \mathrm{~cm} \times 25.4 \mathrm{~cm}$, Whatman) using high volume air samplers (Anderson Model GUV-16HBL, Thermo). Before sampling, filters were pre-heated at $450{ }^{\circ} \mathrm{C}$ for $4 \mathrm{~h}$, then conditioned in a desiccator at $25{ }^{\circ} \mathrm{C}$ and $50 \%$ relative humidity for $24 \mathrm{~h}$ and then weighed to a precision of $\pm 0.1 \mathrm{mg}$ on an electronic balance. After sampling, filter was doubled up, wrapped in a Teflon bag and then stored in the electronic desiccator before analysis. The two samplers were set up at $1.5 \mathrm{~m}$ above the rooftop or ground level and operated simultaneously and continuously at a nominal air flow rate of $1.13 \mathrm{~m}^{3} /$ min for $24 \mathrm{~h}$ in 10 consecutive days from October $29^{\text {th. }}$ to November $8^{\text {th. }}$ of 2006 . It was generally sunny with gentle northern wind, but atmospheric haze was observed within the sampling period. The temperature measured at the sites ranged from 17 to $31^{\circ} \mathrm{C}$ and the relative humidity from 26 to $77 \%$.

\section{Total metal concentration analysis}

Total concentration analysis of trace metals in $\mathrm{PM}_{2.5}$ were performed with an acid digestion method. In brief, the section of each PM sample filter, along with $3 \mathrm{~mL}$ of concentrated nitric acid were placed in a closed Teflon bomb and mixed for 10 min in an ultrasonic system. The bomb was then heated in an oven at $180^{\circ} \mathrm{C}$ for $8 \mathrm{~h}$ for dissolution of the PM. The solution was filtered with a pre-cleaned plastic syringe filter and the filtrate was collected in a Teflon beaker. The Teflon bomb was rinsed for three times with de-ionized water and each followed by filtration. For each sample, the filtrates above were all collected in the same Teflon beaker with a total volume of about $50 \mathrm{~mL}$, and then heated on a hot plate at $110^{\circ} \mathrm{C}$ to reduce the aqueous phase to $1-2 \mathrm{~mL}$. The residual liquid was diluted to a volume of $10 \mathrm{~mL}$ with $2 \%$ 
$\mathrm{HNO}_{3}$, stored in a polyethylene bottle at $4^{\circ} \mathrm{C}$ before analysis.

\section{Chemical speciation analysis}

The four-step sequential extraction procedure developed by Fernández et al. (2002) was followed to fractionate the $\mathrm{PM}_{25}$-bound trace metals into four fractions, including F1 of soluble and exchangeable metals, F2 of carbonates, oxides and reducible metals, F3 of metals bound to organic matter, oxidisable and sulphidic metals and F4 of residual metals such as silicates. The SEP and the regents used for extraction in each step were summarized in Table 1 . In brief, the SEP was carried out with $50 \mathrm{~mL}$ polypropylene centrifuge bottles. Following each extraction step, extracted solutions were separated from the filters by centrifugation at $4200 \mathrm{rpm}$ and at $25^{\circ} \mathrm{C}$ for $10 \mathrm{~min}$. The supernatant of each PM extraction was transferred to a Teflon beaker and the filters were rinsed with the same extracting regent, centrifuged again and the supernatant was decanted into the same Teflon beaker. The combined supernatants were heated until 1-2 mL of solution left, then diluted to a volume of $10 \mathrm{~mL}$ with $2 \% \mathrm{HNO}_{3}$, stored in a polyethylene bottle at $4{ }^{\circ} \mathrm{C}$ before analysis. After the third extraction step, the residuals were treated with the acid digestion method described in section 2.2 for quantification of F4.

\section{Trace metal analysis}

All solution samples were analyzed for 12 trace metals, $\mathrm{Al}, \mathrm{Fe}, \mathrm{Zn}, \mathrm{Pb}, \mathrm{Mn}, \mathrm{Cu}, \mathrm{As}, \mathrm{Cr}, \mathrm{Ni}, \mathrm{Cd}$, Mo and Co using inductively coupled plasma-mass spectrometry(ICP-MS, Agilent 7500A Series). The detection limit of trace elements was $10^{-11}-10^{-14} \mathrm{~g} / \mathrm{mL}$. Calibration of the ICP-MS instrument was performed with multi-element calibration standards from 5 to $500 \mathrm{ng} / \mathrm{mL}$. During the measurement, ${ }^{45} \mathrm{Sc},{ }^{72} \mathrm{Ge},{ }^{115} \mathrm{In}$, and ${ }^{209} \mathrm{Bi}$ at $100 \mathrm{ng} / \mathrm{mL}$ were used as the internal standards to monitor possible instrumental drifting and to compensate the matrix effect. During the acid digestion and sequential extraction procedures, three blank filters were analyzed simultaneously and the sample results were corrected by the average of blank concentrations. The elemental concentrations of the blanks were less than $1 \%$ of the mean concentrations of PM samples for all metals. During the acid digestion, spiked samples were also run with the recovery rates ranged from $93.2 \%$ to $105.9 \%$ and the precision (RSD) of $0.55 \% \sim 2.35 \%$.
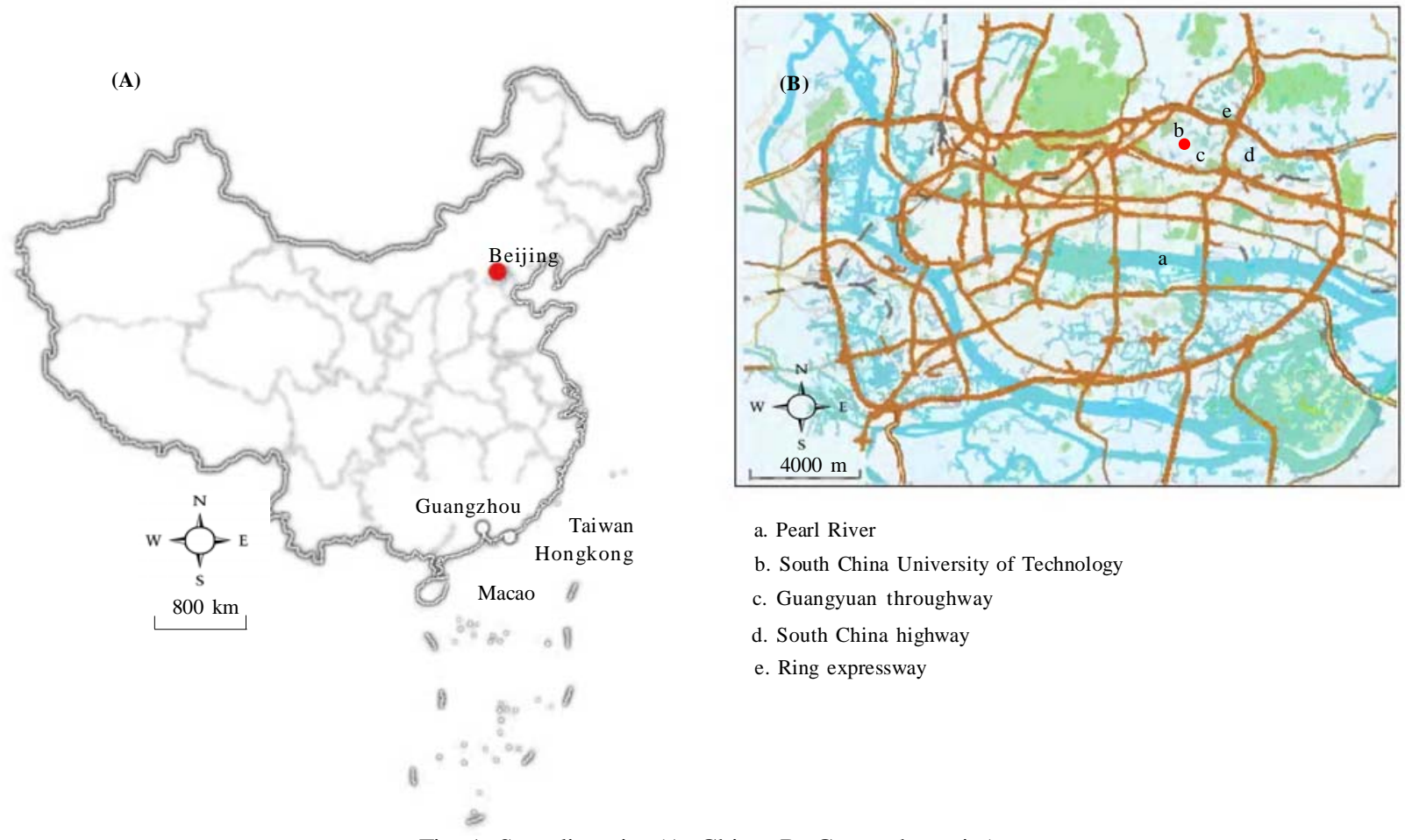

a. Pearl River

b. South China University of Technology

c. Guangyuan throughway

d. South China highway

e. Ring expressway

Fig. 1: Sampling site (A: China; B: Guangzhou city) 
Chemical speciation of $P M_{2.5}$

Table 1: Chemical sequential extraction procedure modified after Fernández et al. (2002)

\begin{tabular}{|c|c|c|}
\hline Metallic fraction & Reagent & Experimental conditions \\
\hline $\begin{array}{l}\text { F1. Soluble and exchangeable } \\
\text { metals }\end{array}$ & $15 \mathrm{~mL} \mathrm{H}_{2} \mathrm{O}(\mathrm{pH}=7.4)$ & $3 \mathrm{~h}$ at room temperature. Shaker agitation \\
\hline $\begin{array}{l}\text { F2. Carbonates, oxides and } \\
\text { reducible metals }\end{array}$ & $10 \mathrm{~mL} \mathrm{NH}_{2} \mathrm{OH} \cdot \mathrm{HCl} 0.25 \mathrm{M}$ at $\mathrm{pH} 2.0$ & $5 \mathrm{~h}$ at room temperature. Shaker agitation \\
\hline $\begin{array}{l}\text { F3. Bound to organic } \\
\text { matter, oxidisable } \\
\text { and sulphidic metals }\end{array}$ & $\begin{array}{l}7.5 \mathrm{~mL} \mathrm{H}_{2} \mathrm{O}_{2} 30 \%+7.5 \mathrm{~mL} \mathrm{H}_{2} \mathrm{O}_{2} \\
30 \%+15 \mathrm{~mL} \mathrm{NH}_{4} \mathrm{OAc} 2.5 \mathrm{M} \text { at } \\
\mathrm{pH}=3.0\end{array}$ & $\begin{array}{l}\text { At } 95{ }^{\circ} \mathrm{C} \text { until near dryness. Shaker agitation }+ \text { at } 95^{\circ} \mathrm{C} \\
\text { until near dryness. Shaker agitation }+90 \mathrm{~min} \text { at room } \\
\text { temperature. Shaker agitation }\end{array}$ \\
\hline F4. Residual metals & $3 \mathrm{~mL} \mathrm{HNO}_{3}$ & $8 \mathrm{~h}$ at $180^{\circ} \mathrm{C}$ \\
\hline
\end{tabular}

\section{RESULTS AND DISCUSSION}

Concentrations of $\mathrm{PM}_{2.5}$ particles and metals

As shown in Fig. 2, the $\mathrm{PM}_{2.5}$ concentrations ranged from 83.3 to $190.0 \mu \mathrm{g} / \mathrm{m}^{3}$ with an average value of 123.2 $\mu \mathrm{g} / \mathrm{m}^{3}$ at the ground level and from 95.8 to $194.7 \mu \mathrm{g} / \mathrm{m}^{3}$ with an average value of $139.7 \mu \mathrm{g} / \mathrm{m}^{3}$ on the roof. The effect of the sampling height on the measured particulate concentration is less obvious likely because the height difference is not sufficiently large.

It should be noted that China currently has no $\mathrm{PM}_{25}$ standard. Resulted $\mathrm{PM}_{2.5}$ concentration data were all higher than the $24 \mathrm{~h} \mathrm{PM}_{2.5}$ standard of $35 \mu \mathrm{g} / \mathrm{m}^{3}$ set by USEPA (2006), indicating that Guangzhou lacks of poor air quality with high concentration of fine particles. All data were comparable to the literature data reported for this region (51.72-187.13 $\mathrm{\mu g} / \mathrm{m}^{3}$ ) (Wang et al., 2006) and generally higher than that of Hong Kong (49.9$56.4 \mu \mathrm{g} / \mathrm{m}^{3}$ ) (Duan et al., 2007). The measurements were also comparable to those of Beijing, China (76.9$126.5 \mu \mathrm{g} / \mathrm{m}^{3}$ ) (Song et al., 2007), but were much higher than the data reported for other worldwide big cities such as New York, USA (10.73-15.48 $\mu \mathrm{m} / \mathrm{m}^{3}$ ) (Qin et al., 2006), Mexico City, Mexico (33.4-70.8 $\left.\mu \mathrm{m} / \mathrm{m}^{3}\right)$ (De Vizcaya-Ruiz et al., 2006), and European cities (7.5-22.6 $\mu \mathrm{m} / \mathrm{m}^{3}$ ) (Puustinen et al., 2007). The total concentrations of 12 trace metals in $\mathrm{PM}_{2.5}$ in units of $\mathrm{ng} / \mathrm{m}^{3}$ are listed in Table 2. It is apparent that the concentrations of each metal in $\mathrm{PM}_{2.5}$ were similar at both sampling levels. Al, $\mathrm{Fe}, \mathrm{Zn}$ and Pb had average concentration of 2081, 1457, 504.8 and $201.6 \mathrm{ng} / \mathrm{m}^{3}$, respectively, at the ground level, which were relatively higher than those of Mn (62.49), $\mathrm{Cu}$ (57.32), $\mathrm{As}$ (24.28), $\mathrm{Cr}$ (7.693), $\mathrm{Ni}$ (6.454), Cd (4.431), Mo (2.046) and Co $\left(0.943 \mathrm{ng} / \mathrm{m}^{3}\right)$. At the roof level, the average concentrations of those 12 elements were 2724 (Al), 1908(Fe), $570.3(\mathrm{Zn}), 212.3(\mathrm{~Pb}), 72.19(\mathrm{Mn}), 53.55$ (Cu), 25.64(As), $9.764(\mathrm{Cr}), 6.345$ (Ni), 4.732 (Cd), 2.185 (Mo) and $0.816 \mathrm{ng} / \mathrm{m}^{3}(\mathrm{Co})$. These data are comparable to those reported by Wang et al., (2006) and Duan et al. (2006) for Guangzhou and Beijing, but are much higher than major cities around the world where more strict emission standards are applied (Ariola et al., 2006; Lee et al., 2003; Louie et al., 2005; Singh et al., 2002).

To identify possible sources of trace metals in $\mathrm{PM}_{2.5}$, an enrichment factor (EF) was calculated with Eq. 1 for each metal as below:

$$
\mathrm{EF}=\frac{[\mathrm{E} / \mathrm{Al}]_{\text {air }}}{[\mathrm{E} / \mathrm{Al}]_{\text {topsoil }}}
$$

Where, EF refers to the degree of enrichment of a given element in the tested sample compared to its relative abundance in background materials (Duce et al., 1975). [E/A1 $]_{\text {air }}$ and $[\mathrm{E} / \mathrm{A} 1]_{\text {topsoil }}$ refer to the concentration ratio of a target metal $\mathrm{E}$ and the reference metal $\mathrm{Al}$ in the $\mathrm{PM}_{2.5}$ sample and in the background topsoil, respectively. The background data of trace metals in topsoils of Guangdong Province, where Guangzhou City is the provincial capital, were used to represent the background level in Guangzhou City (CNEMC, 1990).

In general, $\mathrm{EF}=1$ may suggest that the target element is predominantly originated from background soil material. EF $>1$ implies that the target element may come from other sources, including contamination by human related activities and other processes. The calculation results showed in Table 3 indicated that the 11 metals had EF values of 2.16 (Fe), 406 (Zn), 211 (Pb), $131(\mathrm{Cu}), 8.22(\mathrm{Mn}), 105(\mathrm{As}), 5.13(\mathrm{Cr}), 5.19(\mathrm{Co})$, $16.4(\mathrm{Ni}), 9.81(\mathrm{Mo})$, and $2941(\mathrm{Cd})$ at the ground level, while at the roof level the EF values were 2.13 (Fe), 337 (Zn), $164(\mathrm{~Pb}), 89.7(\mathrm{Cu})$, 7.06 (Mn), 83.3 (As), $4.90(\mathrm{Cr})$, 3.22 (Co), 11.3 (Ni), 7.79 (Mo), and 2355 (Cd). Fe has relatively higher concentrations, but lower enrichment factors $(<10)$, suggesting less enriched and mainly from natural processes such as wind-blown soil dust. By contrast, Cd has very high enrichment factors (> 2000) 
even with relatively low concentration in $\mathrm{PM}_{2.5}$, indicating the sources are predominately from anthropogenic activities. These 11 metals could be divided into three groups according to the calculating results, a highly enriched group with $\mathrm{EF}>100$ (e.g., $\mathrm{Cd}, \mathrm{Pb} \mathrm{Zn}, \mathrm{Cu}$ and $\mathrm{As}$ ), an intermediately enriched group with EF between 10 and 100 (e.g., Ni), and a slightly enriched group with $\mathrm{EF}<10$ (e. g., Mo, Mn, $\mathrm{Cr}$, Co and $\mathrm{Fe}$ ).

\section{Chemical speciation of trace metals}

Chemical speciation data for $\mathrm{PM}_{25}$-bound trace metals obtained by SEP are presented in Table 2 as concentration and in Fig. 3 as percentage distribution. In general, the samples collected from the two different elevations had similar patterns of metal speciation, consistent with the $\mathrm{PM}_{2.5}$ concentration data aforementioned. However, the patterns of the relative distribution among the four fractions differ dramatically

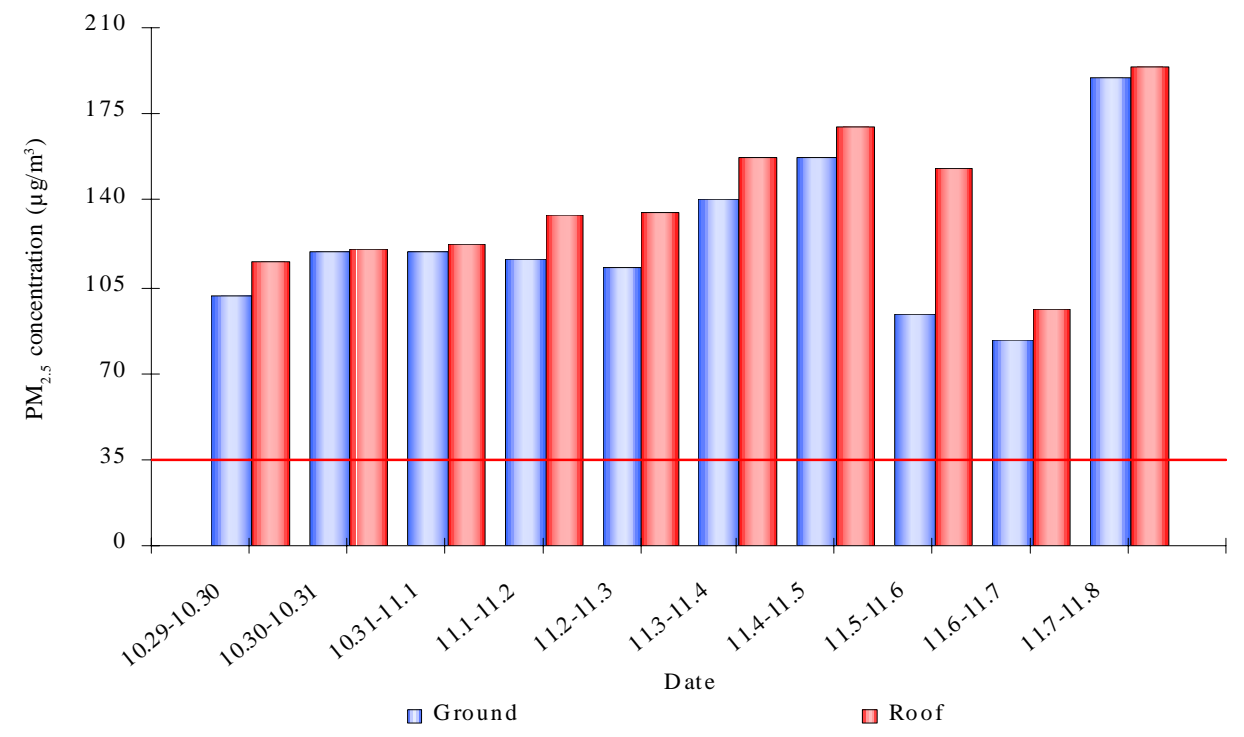

Fig. 2: $\mathrm{PM}_{2.5}$ concentrations over the sampling period (35 $\mu \mathrm{g} / \mathrm{m}^{3}$ is the $24 \mathrm{~h}$ standard set by USEPA)

Table 2: Concentration of trace metals in total and different fractions in $\mathrm{PM}_{2.5}\left(\mathrm{ng} / \mathrm{m}^{3}\right)$

\begin{tabular}{|c|c|c|c|c|c|c|c|c|c|c|c|c|}
\hline Element & Total & F1 & $\mathrm{F} 2$ & F3 & $\mathrm{F} 4$ & $\frac{\text { Total }-\sum_{\mathrm{i}=1}^{4} \mathrm{Fi}}{\text { Total }}$ & Total & $\mathrm{F} 1$ & $\mathrm{~F} 2$ & F3 & $\mathrm{F} 4$ & $\begin{array}{c}\text { Total }-\sum_{\mathrm{i}=1}^{4} \mathrm{Fi} \\
\text { Total } \\
(\%)\end{array}$ \\
\hline $\mathrm{Al}$ & 2081 & 27.32 & 162.0 & 454.8 & 1226 & 10.0 & 2724 & 33.38 & 179.2 & 573.1 & 1607 & 12.1 \\
\hline $\mathrm{Pb}$ & 201.6 & 24.60 & 157.8 & 26.84 & 4.256 & 5.9 & 212.3 & 27.01 & 167.2 & 29.41 & 3.805 & 7.1 \\
\hline Mn & 62.49 & 18.91 & 18.25 & 14.82 & 6.872 & 5.8 & 72.19 & 22.78 & 20.18 & 17.82 & 7.363 & 5.6 \\
\hline $\mathrm{Cu}$ & 57.32 & 11.78 & 23.89 & 19.32 & 1.324 & 1.7 & 53.55 & 12.03 & 20.33 & 19.05 & 1.509 & 1.2 \\
\hline As & 24.28 & 7.913 & 6.744 & 3.955 & 1.091 & 18.8 & 25.64 & 9.118 & 6.194 & 4.456 & 1.218 & 18.1 \\
\hline $\mathrm{Cr}$ & 7.693 & 0.504 & 0.602 & 1.925 & 3.121 & 20.0 & 9.764 & 0.502 & 0.789 & 2.023 & 4.570 & 19.3 \\
\hline $\mathrm{Ni}$ & 6.454 & 1.779 & 0.561 & 2.346 & 0.9737 & 12.3 & 6.345 & 1.479 & 0.766 & 2.182 & 1.019 & 14.2 \\
\hline
\end{tabular}

F1: soluble and exchangeable metals; F2: carbonates, oxides and reducible metals; F3: bound to organic matter, oxidisable and sulphidic metals;

F4: residual metals 

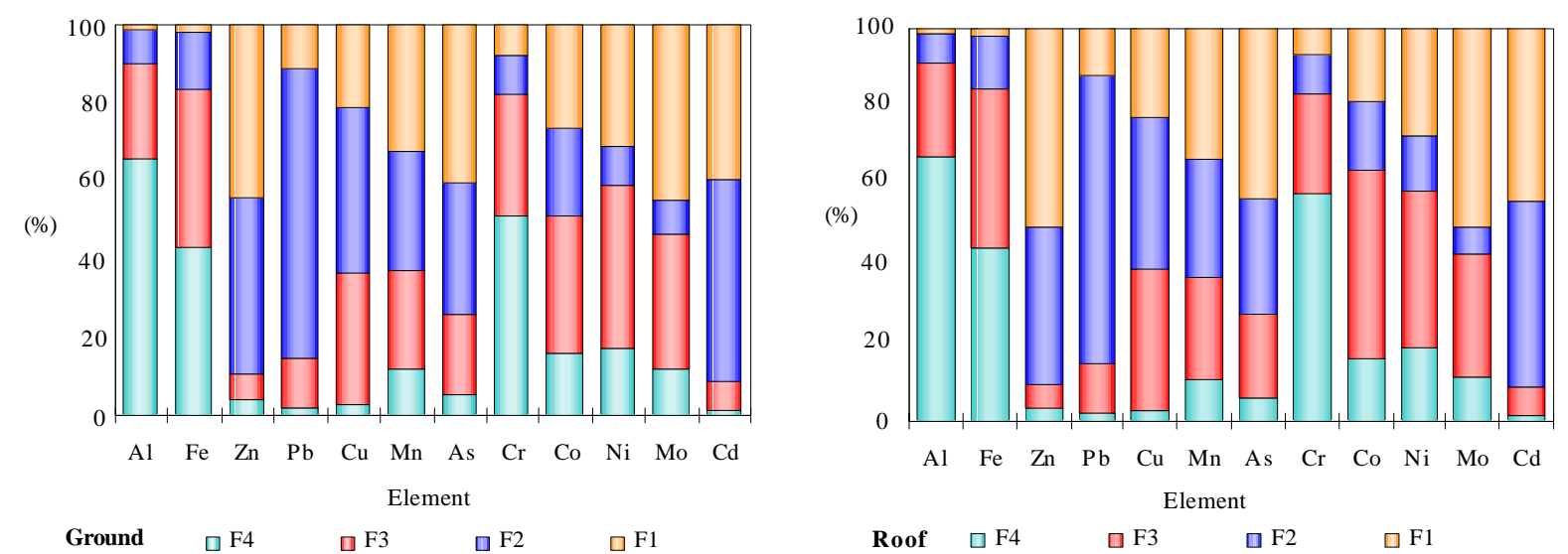

Fig. 3: Chemical speciation distribution of $\mathrm{PM}_{25}$-bound metals as percentage (F1: soluble and exchangeable metals; F2: carbonates, oxides and reducible metals; F3: bound to organic matter, oxidisable and sulphidic metals; F4: residual metals)

Table 3: Mass concentration and enrichment factor of trace metals in $\mathrm{PM}_{2.5}$

\begin{tabular}{lccrrr}
\hline \multirow{2}{*}{ Element } & $\begin{array}{c}\text { Background value } \\
\text { in topsoil }(\mathrm{mg} / \mathrm{kg})\end{array}$ & \multicolumn{2}{c}{ Ground } & \multicolumn{2}{c}{ Roof } \\
\cline { 3 - 6 } & $7.21 \times 10^{4}$ & 16187 & Concentration $(\mathrm{mg} / \mathrm{kg})$ & Concentration $(\mathrm{mg} / \mathrm{kg})$ & $\mathrm{EF}$ \\
\hline $\mathrm{Al}$ & $2.42 \times 10^{4}$ & 11711 & 2.16 & 18974 & 1 \\
$\mathrm{Fe}$ & 47.3 & 4313 & 406 & 13583 & 2.13 \\
$\mathrm{Zn}$ & 36.0 & 1703 & 211 & 4195 & 337 \\
$\mathrm{~Pb}$ & 279 & 515.0 & 8.22 & 1557 & 764 \\
$\mathrm{Mn}$ & 17.0 & 499.4 & 131 & 401.2 & 89.7 \\
$\mathrm{Cu}$ & 8.90 & 209.5 & 105 & 195.1 & 83.3 \\
$\mathrm{As}$ & 50.5 & 58.11 & 5.13 & 65.14 & 4.90 \\
$\mathrm{Cr}$ & 14.4 & 53.04 & 16.4 & 42.99 & 23.3 \\
$\mathrm{Ni}$ & 0.06 & 36.97 & 2941 & 34.71 & 7.79 \\
$\mathrm{Cd}$ & 7.70 & 16.96 & 9.81 & 15.78 & 3.22 \\
$\mathrm{Mo}$ & 7.00 & 8.160 & 5.19 & 5.936 & \\
$\mathrm{Co}$ & & & & & \\
\hline
\end{tabular}

among the 12 metals. As shown in Fig. 3, more than $40 \%$ of $\mathrm{Zn}, \mathrm{Mo}$, Cd and As and more than $30 \%$ of $\mathrm{Ni}$ and $\mathrm{Mn}$ in the $\mathrm{PM}_{2.5}$ samples were soluble and exchangeable (F1) whereas more than $70 \%$ of $\mathrm{Pb}$, more than $40 \%$ of Cd, Zn, Cu and more than $30 \%$ of Mn and As were in carbonates, oxides and reducible forms (F2). Meanwhile, more than $40 \%$ of $\mathrm{Ni}$ and Fe and more than $30 \%$ of $\mathrm{Co}, \mathrm{Mo}, \mathrm{Cr}$ and $\mathrm{Cu}$ were either associated with organic matter, or in oxidisable and sulphidic forms (F3). $\mathrm{Al}(>60 \%), \mathrm{Cr}(>50 \%)$, and $\mathrm{Fe}(>40 \%)$ were the dominant metals in the residual forms (F4). When compared to previous studies on total suspended particles (TSP) collected from Guangzhou, data indicated that $\mathrm{PM}_{25}$ contained much higher soluble and exchangeable fractions of the bound metals. Lv et al. (2005) used the Tessier's sequential extraction procedure to fractionate TSP-bound trace metals into four fractions. They found that the exchangeable fractions of $\mathrm{Cu}, \mathrm{Pb}$, and $\mathrm{Zn}$ were about $5.5 \%, 7.6 \%$ and $4.0 \%$, respectively. These data were much lower than collected data presented in Fig. 3 likely because metals associated in larger size particles had relatively lower concentration in the soluble fraction. Wei et al. (1999) studied metal concentrations bound to $\mathrm{PM}_{10}, \mathrm{PM}_{2.5}$ and $\mathrm{PM}_{2.5-10}$ collected from four major cities of China including Guangzhou during 1995 and 1996. They found that $\mathrm{PM}_{2.5}$ constituted about 52-75\% of $\mathrm{PM}_{10}$ and the total concentrations of heavy metals in $\mathrm{PM}_{2.5}$ (e.g., $476 \mathrm{ng} / \mathrm{m}^{3}$ of $\mathrm{Pb}$ and $40.4 \mathrm{ng} / \mathrm{m}^{3}$ of As) were much higher than that in $\mathrm{PM}_{2.5-10}$ (e.g., $104 \mathrm{ng} / \mathrm{m}^{3}$ of $\mathrm{Pb}$ and $8.0 \mathrm{ng} / \mathrm{m}^{3}$ of As).

Collected data were compared with previous studies on airborne $\mathrm{PM}_{2.5}$ of other countries. The chemical speciation of Fe and Mn presented in this study were comparable to that of Seville City (Spain) reported by Fernández et al. (2002). However, $\mathrm{Pb}$ and $\mathrm{Cd}$ in $\mathrm{F} 1$ were only $3.8 \%$ and $24.9 \%$, respectively and $\mathrm{Pb}$ and $\mathrm{Cd}$ in F2 were $33.2 \%$ and $20.6 \%$, respectively, of the total $\mathrm{Pb}$ and $\mathrm{Cd}$ in the PM samples of the Seville City. These 
values were lower than data presented in Fig. 3 and the difference might be due to the different sources of airborne metals of the two cities. There were limited industrial activities in Seville City and that $\mathrm{PM}_{2.5}$-bound $\mathrm{Pb}$ and $\mathrm{Cd}$ were mainly from vehicular traffic. However, sources of $\mathrm{PM}_{2.5}$-bound metals in studies were more complicated. Automobile emissions, industrial and constructions activities and even activities from the research laboratories adjacent to the sampling site might contribute to the presence of $\mathrm{Pb}$ and $\mathrm{Cd}$. Heal et al. (2005) collected $\mathrm{PM}_{2.5}$ samples from Edinburgh, UK and analyzed for the total and water soluble metal concentrations. Their results showed that more than half of the total $\mathrm{V}, \mathrm{Zn}, \mathrm{Cd}, \mathrm{As}, \mathrm{Cu}$ and $\mathrm{Pb}$ in $\mathrm{PM}_{2.5}$ samples, about 25-45 \% of Ni, Mn, and $\mathrm{Cr}$ and approximately 10 $\%$ of $\mathrm{Ti}$ and Fe were water soluble. However, they did not analyze other fractions such as acid soluble and oxidizable fractions for the $\mathrm{PM}_{2.5}$-bound metals. The bioavailability of metals is likely correlated to the chemical speciation determined with SEP (Fernández et al., 2000). According to the extraction method, the chemical activity and availability of the $\mathrm{PM}_{2.5}$ bound metals should decrease on the order of F1 $>$ F2 $>$ F3 $>$ F4. Trace metals in F1 are possibly adsorbed on particle surfaces and are easily released to aqueous solutions. This fraction of the trace metals is readily bioavailable once inhaled to the respiratory system, possessing the greatest risk to human health. Metals in F2 are the fractions susceptible to $\mathrm{pH}$ changes and redox conditions. They can be easily dissolved under acidic aquatic conditions and could be continuously dissolving even under slightly acidic or neutral $\mathrm{pH}$ conditions. Metals in F3 are usually found to be bound on organic matter such as water-insoluble humic-like materials and oxidizable minerals. When the value of oxidation-reduction potential (Eh) increased, organic and inorganic matrices that bind the metals could be degraded, leading to a release of soluble trace metals. The residual fraction (F4) contains metals mainly the form of silicates, cements, passivated oxides and that ought to be extracted under hard acid conditions.

Assuming that the first two fractions (F1 and F2) are labile and completely bioavailable, a bioavailability index (BI) can be calculated according to Eq. 2:

$$
\mathrm{BI}=\frac{\mathrm{F} 1+\mathrm{F} 2}{\sum_{\mathrm{i}=1}^{4} \mathrm{Fi}}
$$

The calculated BI values are presented in Fig. 4 for the 12 metals. From the results, it is clear that $\mathrm{Cd}$ and $\mathrm{Zn}$ had the highest bioavailability indexes ( 0.9), followed by $\mathrm{Pb}(\sim 0.85)$ and $\mathrm{As}(\sim 0.7)$. $\mathrm{Mn}, \mathrm{Cu}$ and $\mathrm{Mo}$ had BI values of around 0.6 whereas Co and Ni had slightly lower $\mathrm{BI}$ values of about 0.4 . The last three metals, Cr, Fe and Al, had the lowest BI values of less than 0.2. It should be noted that $\mathrm{Cd}, \mathrm{Pb}$ and $\mathrm{As}$ are the most toxic metals and that these three metals have very high enrichment factors in $\mathrm{PM}_{2.5}$ samples. Their greater BI values indicate that they may be fully available to physiological activities once inhaled to lung system, which might possess higher risk to human health.

\section{Risk assessment}

Metals bound in $\mathrm{PM}_{2.5}$ can easily get deep into human lung tissues through breathing. Accumulation of these metals, including arsenic, cadmium, chromium, and nickel are carcinogens and through inhalation over extended time period may cause serious health risks (Friberg et al., 1986).

To further demonstrate the risks of the $\mathrm{PM}_{2.5}$-bound metals, As, Cr, Ni and Cd were selected to calculate the incremental lifetime cancer risk. These four elements are defined as contaminants of 1 classification by the International Agency for Research on Cancer (IARC). The cancer potency factors of $\mathrm{Cr}$, As, Cd and $\mathrm{Ni}$ are 41, 15, 6.3 and 0.84 (mg/kg/day), respectively, according to the air toxics reported by VAPCD (1998). The incremental lifetime cancer risks can be calculated by multiplying the cancer potency

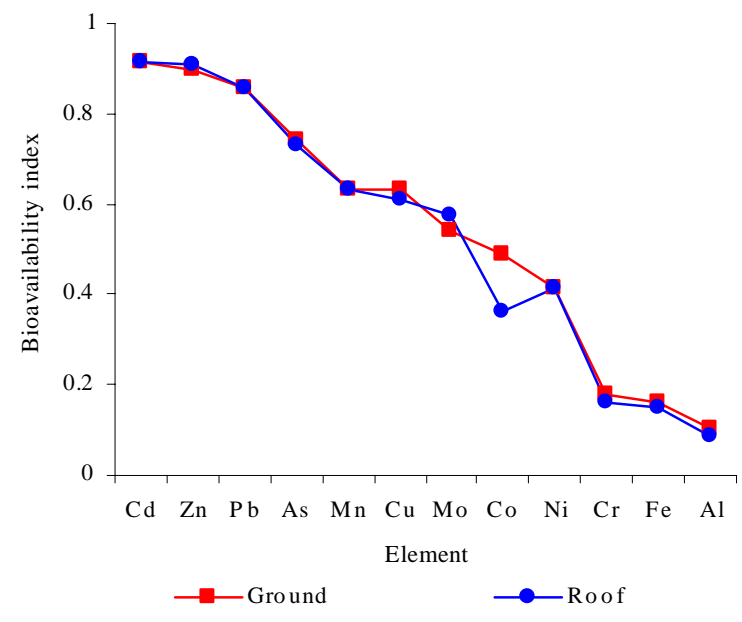

Fig. 4: Bioavailability index of $\mathrm{PM}_{2.5}$-bound metals 
factor of a given carcinogen with the chronic daily intake (CDI). Assume that a person with $60 \mathrm{~kg}$ of body weight has been exposed to the atmosphere over a 30 y period of time and breathed in $20 \mathrm{~m}^{3} /$ day of air. For a life time of $70 \mathrm{y}$, the CDI of this person can be computed from the equation (3) and the relative incremental lifetime cancer risk can be calculated following by the CDI results. Results of CDI and incremental lifetime cancer risk of As, Cr, Ni and Cd were listed in Table 4.

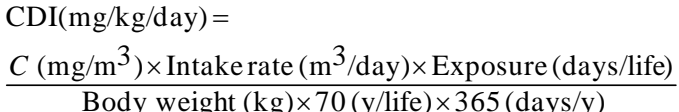

Where, $C$ is the concentration of the toxic substance in the air and intake rate is the amount of air that a person inhaled each day.

When the total concentrations of metals were used as $C$ in equation (3), the cancer risks of $\mathrm{As}, \mathrm{Cr}, \mathrm{Cd}$ and Ni were $52.03 \times 10^{-6}, 45.06 \times 10^{-6}, 3.988 \times 10^{-6}$ and $0.774 \times 10^{-6}$ at the ground level. When the concentrations of the bioavailable fractions (F1 + F2) were applied, the results changed to $31.41 \times 10^{-6}, 6.478$ $\times 10^{-6}, 3.582 \times 10^{-6}$ and $0.281 \times 10^{-6}$ for As, $\mathrm{Cr}$, Cd and Ni, respectively.

It should be noted that the usual goal of cancer risk is set at $1 \times 10^{-6}$ which corresponds to a lifetime exposure to unpolluted ambient environment. The above estimations show that the incremental lifetime cancer risks of As, Cr and Cd were higher than such usual goal, suggesting potential health risks for the residents. When only the bioavailable form is considered, the estimated cancer risks of both As and Cd were little changed because of their high BI value $(>0.7)$. However, because of its low BI value $(<0.2)$, the cancer risk of $\mathrm{Cr}$ decreased from $45.06 \times 10^{-6}$ to $6.478 \times 10^{-6}$ when the bioavailable was used for the calculation. Apparently, bioavailable forms, rather than the total contents, of trace metals in air-borne $\mathrm{PM}_{2.5}$ should be used in order to more accurately assess environmental and health risks. Chemical speciation of metal in PM is hence important and should become a routine analysis in future study of air pollution.

\section{CONCLUSION}

This study showed that concentrations of $\mathrm{PM}_{25}$ samples collected from Guangzhou, China, were much higher than the US-EPA standard set for $24 \mathrm{~h} \mathrm{PM}_{2.5}$. The total concentrations of $\mathrm{PM}_{2.5}$ bound trace metals were several times greater than the literature data reported for major cities around the world. The results of sequential extraction procedure indicated that majority of the bound metals were associated in the two labile phases (F1 and F2), which are either water soluble or acid soluble. These labile phases are considered to be bioavailable once $\mathrm{PM}_{2.5}$ is inhaled to the respiratory system of human beings. The BI values calculated for the 12 metals were on the order of $\mathrm{Cd}>$ $\mathrm{Zn}>\mathrm{Pb}>\mathrm{As}>\mathrm{Mn}>\mathrm{Cu}>\mathrm{Mo}>\mathrm{Co}>\mathrm{Ni}>\mathrm{Cr}>\mathrm{Fe}>\mathrm{Al}$, with $\mathrm{Cd}, \mathrm{Zn}, \mathrm{Pb}$ and As having $\mathrm{BI}$ values $>0.7$. This suggested that most toxic metals associated in $\mathrm{PM}_{2.5}$ were mainly bioavailable. Risk calculations with a simple exposure assessment model showed that the cancer risks of the bioavailable fractions of $\mathrm{As}, \mathrm{Cr}$ and $\mathrm{Cd}$ were 3 to 33 times greater than the usual goal. This study indicated that air particle pollution may possess serious health risks to the residents in this rapidly developing and greatly populated city.

\section{ACKNOWLEDGEMENTS}

This study was supported financially by a key project of National Science Foundation of China (40730741), open foundation of State Key Laboratory of

Table 4: The incremental lifetime cancer risk of As, Cr, Ni and Cd in $\mathrm{PM}_{2.5}$

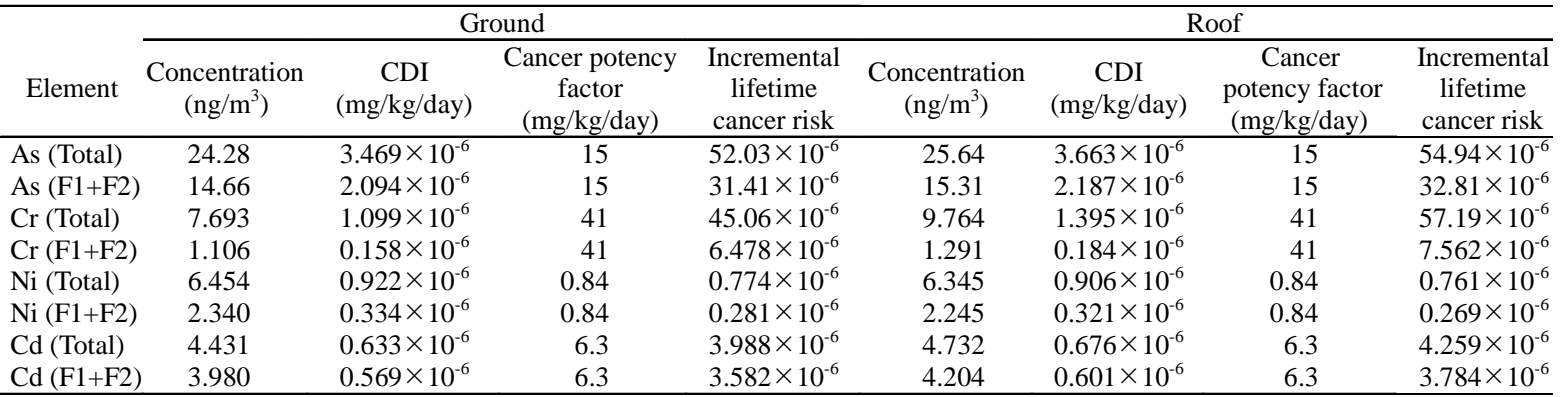


Environmental Geochemistry of China and the Science and Technology Program of Guangdong Province (Key Project No. 2004A30308002 and Grant No. 2004B20501006) to Dang and The State Scholarship Fund of China Scholarship Council (No. 2007U33019) to Feng. The authors would like to thank professor Guoying Sheng, professor Xinhui Bi and Dr. Jihua Tan, all at Guangzhou Institute of Geochemistry, Chinese Academy of Sciences, for their assistance in the sampling phase of this study. Authors are also grateful to Dr. Peter Strom of Rutgers University for the proofread of the early version of the manuscript.

\section{REFERENCES}

Adamson, I. Y. R.; Prieditis, H.; Hedgecock, C.; Vincent, R., (2000). Zinc is the toxic factor in the lung response to an atmospheric particulate sample. Toxicol. Appl. Pharm., 166 (2), 111-119 (9 pages).

Ariola, V.; D’Alessandro, A.; Lucarelli, F.; Marcazzan, G.; Mazzei, F.; Nava, S.; Garcia-Orellana, I.; Prati, P.; Valli, G.; Vecchi, R.; Zucchiatti, A., (2006). Elemental characterization of $\mathrm{PM}_{10}, \mathrm{PM}_{2.5}$ and $\mathrm{PM}_{1}$ in the town of Genoa (Italy). Chemosphere, 62 (2), 226-232 (7 pages).

Banerjee, A. D. K., (2003). Heavy metal levels and solid phase speciation in street dusts of Delhi, India. Environ. Pollut., 123 (1), 95-105 (11 pages).

CNEMC, (1990). Background value of soil elements in China, $1^{\text {st. }}$ Ed., China National Environmental Monitoring Center. Chinese Environmental Science Press, Beijing, 87-90.

Davidson, C. M.; Duncan, A. L.; Littlejohn, D.; Ure, A. M.; Garden, L. M., (1998). A critical evaluation of the threestage BCR sequential extraction procedure to assess the potential mobility and toxicity of heavy metals in industrially-contaminated land. Anal. Chim. Acta., 363 (1), 45-55 (11 pages).

De Vizcaya-Ruiz, A.; Gutiérrez-Castillo, M. E.; Uribe-Ramirez, M.; Cebrián, M. E.; Mugica-Alvarez, V.; Sepúlveda, J.; Rosas, I.; Salinas, E.; Garcia-Cuéllar, C.; Martínez, F.; AlfaroMoreno, E.; Torres-Flores, V.; Osornio-Vargas, A.; Sioutas, C.; Fine, P. M.; Singh, M.; Geller, M. D.; Kuhn, T.; Miguel, A. H.; Eiguren-Fernandez, A.; Schiest, R. H.; Reliene, R.; Froines, J., (2006). Characterization and in vitro biological effects of concentrated particulate matter from Mexico City. Atmos. Environ., 40 (S2), 583-592 (10 pages).

Duan, F. K.; He, K. B.; Ma, Y. L.; Yang, F. M.; Yu, X. C.; Cadle, S. H.; Chan, T.; Mulawa, P. A., (2006). Concentration and chemical characteristics of $\mathrm{PM}_{2.5}$ in Beijing, China: 20012002. Sci. Total Environ., 355 (1-3), 264-275 (12 pages).

Duan, J. C.; Tan, J. H.; Cheng, D. X.; Bi, X. H.; Deng, W. J.; Sheng, G. Y.; Fu, J. M.; Wong, M. H., (2007). Sources and characteristics of carbonaceous aerosol in two largest cities in Pearl River Delta Region, China. Atmos. Environ., 41 (14), 2895-2903 (9 pages).

Duce, R. A.; Hoffman, G. L.; Zoller, W. H., (1975). Atmospheric trace metals at remote northern and southern hemisphere sites: Pollution or natural? Science, 187 (4171), 59-61 (3 pages).
Fernández Espinosa, A. J.; Ternero Rodríguez, M.; Barragán, de, la, Rosa, F. J.; Jiménez, Sánchez, J. C., (2000). An approach to characterization of sources of urban airborne particles through heavy metal speciation. Chemos. Glob. Change Sci., 2 (2), 123-136 (14 pages).

Fernández Espinosa, A. J.; Ternero Rodríguez, M.; Barragán, de, la, Rosa, F. J.; Jiménez, Sánchez, J. C., (2002). A chemical speciation of trace metals for fine urban particles. Atmos. Environ., 36 (5), 773-780 (8 pages).

Friberg, L.; Nordberg, G. F.; Vouk, V. B., (1986). Handbook on the toxicology of metals, $2^{\text {nd. }}$ Ed., Elsevier Science and Technology, 5-6.

Gómez, D.; Dos Santos, M.; Fujiwara, F.; Polla, G.; Marrero, J.; Dawidowski, L.; Smichowski, P., (2007). Fractionation of metals and metalloids by chemical bonding from particles accumulated by electrostatic precipitation in an Argentine thermal power plant. Microchem J., 85 (2), 276-284 (9 pages).

Heal, M. R.; Hibbs, L. R.; Agius, R. M.; Beverland, I. J., (2005). Total and water-soluble trace metal content of urban background $\mathrm{PM}_{10}, \mathrm{PM}_{2.5}$ and black smoke in Edinburgh, UK. Atmos. Environ., 39 (8), 1417-1430 (14 pages).

Karbassi, A. R.; Shankar, R. (1994). Magnetic susceptibility of bottom sediments and suspended particulates from MulkiPavanje River, estuary, and adjoining shelf, west coast of India. J. Geophysic. Res., 99 (5), 10207-10220 (14 pages).

Lee, P. K. H.; Brook, J. R.; Dabek-Zlotorzynska, E.; Mabury, S. A., (2003). Identification of the major sources contributing to $\mathrm{PM}_{2.5}$ observed in Toronto. Environ. Sci. Tech., 37 (21), $4831-4840$ (10 pages).

Lee, C. S. L.; Li, X. D.; Zhang, G.; Li, J.; Ding, A. J.; Wang, T., (2007). Heavy metals and $\mathrm{Pb}$ isotopic composition of aerosols in urban and suburban areas of Hong Kong and Guangzhou, South China-Evidence of the long-range transport of air contaminants. Atmos. Environ., 41 (2), 432-447 (16 pages).

Louie, P. K. K.; Chow, J. C.; Chen, L. W. A.; Watson, J. G.; Leung, G.; Sin, D. W. M., (2005). PM $_{2.5}$ chemical composition in Hong Kong: Urban and regional variations. Sci. Total Environ., 338 (3), 267-281 (15 pages).

Lv, X. W.; Chen, C. Y.; Huang, R. D.; Dang, Z., (2005). Speciation analysis and transfer of heavy metals in atmospheric particulates. J. S. China U. Technol., 33 (1), 75-78 (4 pages).

Ormstad, H., (2000). Suspended particulate matter in indoor air: Adjuvants and allergen carriers. Toxicology, 152 (1-3), 53-68 (16 pages).

Peters, A.; Dockery, D. W.; Muller, J. E.; Mittleman, M. A., (2001). Increased particulate air pollution and the triggering of myocardial infarction. Circulation, 103 (23), 2810-2815 (6 pages).

Puustinen, A.; Hämeri, K.; Pekkanen, J.; Kulmala, M.; Hartog, J. D.; Meliefste, K.; Brink, H. T.; Kos, G.; Katsouyanni, K.; Karakatsani, A.; Kotronarou, A.; Kavouras, I.; Meddings, C.; Thomas, S.; Harrison, R.; Ayres, J. G.; Zee, S. V. D.; Hoek, G., (2007). Spatial variation of particle number and mass over four European cities. Atmos. Environ., 41 (31), 6622-6636 (15 pages).

Qin, Y. J.; Kim, E.; Hopke, P. K., (2006). The concentrations and sources of $\mathrm{PM}_{2.5}$ in metropolitan New York City. Atmos. Environ., 40 (S2), 312-332 (21 pages). 
Sammut, M. L.; Noack, Y.; Rose, J., (2006). Zinc speciation in steel plant atmospheric emissions: A multi-technical approach. J. Geochem. Explor., 88 (1-3), 239-242 (4 pages).

Singh, M.; Jaques, P. A.; Sioutas, C., (2002). Size distribution and diurnal characteristics of particle-bound metals in source and receptor sites of the Los Angeles Basin. Atmos. Environ., 36 (10), 1675-1689 (15 pages).

Song, Y.; Tang, X. Y.; Xie, S. D.; Zhang, Y. H.; Wei, Y. J.; Zhang, M. S.; Zeng, L. M.; Lu, S. H., (2007). Source apportionment of $\mathrm{PM}_{2.5}$ in Beijing in 2004. J. Hazard Mater., 146 (1-2), 124-130 (7 pages).

Sun, G. B.; Crissman, K.; Norwood, J.; Richards, J.; Slade, R.; Hatch, G. E., (2001). Oxidative interactions of synthetic lung epithelial lining fluid with metal-containing particulate matter. Am. J. Physiol. Lung. Cell. Mol. Physiol., 281 (4), L807-L815 (9 pages).

Tessier, A.; Campbell, P. G. C.; Bisson, M., (1979). Sequential extraction procedure for the speciation of particulate trace metals. Anal. Chem., 51(7), 844-851 (8 pages).

Ure, A. M.; Quevauviller, P. H.; Muntau, H.; Griepink, B., (1993). Speciation of heavy metals in soils and sediments. An account of the improvement and harmonization of extraction technique undertaken under the auspices of the
BCR of the Commission of the European Community. Int. J. Environ. An. Ch., 51 (1), 135-151 (17 pages).

USEPA, (2006). Office of air and radiation, Office of Air Quality Planning and Standards, Fact Sheet. United States Environmental Protection Agency, National Ambient Air Quality Standards (NAAQS). http://www.epa.gov/air/ criteria.html.

Usero, J.; Gamero, M.; Morillo, J.; Gracia, I., (1998). Comparative study of three sequential extraction procedures for metals in marine sediments. Environ. Int., 24 (4), 487496 (10 pages).

VAPCD, (1998). The air toxics report Appendix A, Category I-Algorithm and Tables. The Vermont Air Pollution Control Division, http:///www.anr.state.vt.us/air/AirToxics/docs/ AirToxReportAppendix_A.pdf.

Wang, X. H.; Bi, X. H.; Sheng, G. Y.; Fu, J. M., (2006). Chemical composition and sources of $\mathrm{PM}_{10}$ and $\mathrm{PM}_{2.5}$ aerosols in Guangzhou, China. Environ. Monit. Assess., 119 (1-3), 425439 (15 pages).

Wei, F.; Teng, E.; Wu, G.; Hu, W.; Wilson, W. E.; Chapman, R. S.; Pau, J. C.; Zhang, J., (1999). Ambient concentrations and elemental compositions of $\mathrm{PM}_{10}$ and $\mathrm{PM}_{2.5}$ in four Chinese cities. Environ. Sci. Tech., 33 (23), 4188-4193 (6 pages).

\section{AUTHOR (S) BIOSKETCHES}

Feng, X. D., Ph.D. candidate, School of Environmental Science and Engineering, South China University of Technology, Guangzhou Higher Education Mega Center, Guangzhou, 510006, P.R. China. Visiting Ph.D. candidate, Department of Environmental Sciences, Rutgers University, New Brunswick, New Jersey, 08901-8551, USA. Email: fengxidan@yahoo.com.cn

Dang, Z., Ph.D., Professor, School of Environmental Science and Engineering, South China University of Technology, Guangzhou Higher Education Mega Center, Guangzhou, 510006, P.R. China. Email: chzdang@scut.edu.cn

Huang, W. L., Ph.D., Associate professor, Department of Environmental Sciences, Rutgers University, New Brunswick, New Jersey, 08901-8551, USA. E-mail: whuang@envsci.rutgers.edu

Yang, C., Ph.D., School of Environmental Science and Engineering, South China University of Technology, Guangzhou Higher Education Mega Center, Guangzhou, 510006, P.R. China. Email: cyanggz@scut.edu.cn 